Исидора М. Каловић"

Универзитет у Београду

Филолошки факултет
821.134.2(82).09-31 Валенсуела Л. https://doi.org/10.18485/analiff.2019.31.2.6

Originalni naučni rad

Primljen: 23.06.2019

Prihvaćen: 18.08.2019

\title{
ПОСТМОДЕРНА ИНТЕРТЕКСТУАЛНОСТ У ПРИЧАМА ЛУИСЕ ВАЛЕНСУЕЛЕ
}

У раду испитујемо и анализирамо присуство постмодерне интертекстуалности, коју првобитно теоријски дефинишемо, у причама из збирке $\mathrm{Cu}$ метирије (Simetrías) аргентинске ауторке Луисе Валенсуеле (Luisa Valenzuela). У поглављу Бајке из йакла (Cuentos de Hades) Валенсуела се надовезује на дечије бајке и у свих шест прича присутни су заједнички поступци трансформације интертекстова приликом њиховог поновног исписивања. Увиђамо да нови смисао текста настаје пародирањем бајки чије традиционално тумачење и поруке су предмет критике. Ауторка наводи читаоца на преиспитавање вредности које друштво и традиција намећу, нарочито оних вредности које се односе на улогу жене у друштву. Због заступљености интертекстова у овој мери, пародије, критике, ангажованости, преиспитивања ауторитета и традиције, ове приче су постмодерне, као и интертексталност која се у њима успоставља.

Кључне речи: Луиса Валенсуела, постмодернизам, интертекстуалност, постмодерна интертекстуалност, интертекст, бајка, прича

\section{1. Увод у интертекстуалност}

Џералд Принс (Gerald Prince) (2011: 76) појам интертекстуалности дефинише као „однос(е) какве имамо између неког текста и других текстова које први цитира, наново исписује, апсорбује, продужава или, уопште узев, трансформише и посредством којих постаје разумљив."

Када је Јулија Кристева (Julia Kristeva) шездесетих година 20.

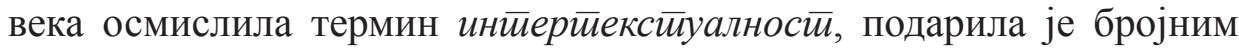
пређашњим концепцијама заједнички назив. Овај неологизам суштин-

\footnotetext{
*_isidorakalovic@gmail.com

1 Prince, G. (2003). Dictionary of Narratology. University of Nebraska Press
} 
ски није означио неку нову тенденцију у књижевности, већ је постао одредница за појаву која је стара готово као и сама књижевност. Полазећи од Бахтинове (Михаи́л Миха́йлович Бахти́н) идеје о дијалогичности и дијалошком карактеру саме речи, интертекстуалност Кристеве постаје концепција према којој сваки књижевни текст садржи раније текстове и представља мозаик различитих позајмица (Бужињска, 2009: 363). Текст је дакле, као и код Бахтина, процес или „интертекстуално отворена продуктивност“, а не заокружена целина која носи поруку свога аутора (Јуван, 2013: 119). Према теорији интертекстуалности, анализа књижевног дела има за циљ да препозна текстове, односно позајмице уткане у текст који је предмет анализе и тако представи процес његовог стварања (Бужињска, 2009: 365). Интерпретације могу бити бројне, значење текста није јединствено, већ многостурко, а важну улогу у процесу стварања дела и његовог смисла има читалац:

„Рађање смисла у новом тексту за Кристеву је пре свега представљало додиривање различитих значења и традиција и - што је најважније - тај процес се никад није завршавао. Она је у њему видела активну улогу читаоца као саучесника и настављача интертекстуалног дијалога - управо је читалац започињао овај дијалог и настављао га кроз поступке читања.“ (Бужињска, 2009: 364)²

Иако је Јулија Кристева понајвише развијала теорију интертекстуалности у оквиру постструктурализма и на појединим примерима показала како функционише интертекстуална анализа, јасно је да су само теорија и интертекстуална анализа у том тренутку биле новина, а не и сам феномен интертекстуалности. Поред саме појаве, која је предуслов за анализу, у теорији су такође постојале идеје које се могу сматрати претечама теорија дијалогичности и интертекстуалности из 20. века. То би биле оне концепције које текст тумаче као надовезивање на традицију, друге текстове, идеје, мотиве, теме и међу њима Марко Јуван (Marko Juvan) (2013: 59) издваја основе поетике и реторике које су поставили Платон, Аристотел, Цицерон, Хорације и Квитилијан као најближе савременим представама о интертекстуалности:

2 Burzyńska, A, Markowski, MP. (2006). Teorie literatury XX wieku. Kraków: Wydawniczy ZNAK 
„[...] С концепцијом подражавања су стварање и разумевање говора/текста баш тако изводили из друштвено-културних и традицијских дискурса: вредновање имитације је подразумевало поређење са предлошком, присутно у сећању публике макар латентно, а то се подудара са цитатношћу. Подражавање је коначно покривало поступке којима су говорници/писци трансформисали предлошке и тако формулисали другачије поруке-и овде је аналогија са представама J. Кристеве очигледна.“ (Јуван, 2013: 59)3

Бројни су начини да се један текст надовеже на неки други, те постоје различите форме и врсте интертекстуалности попут цитата, алузије, парафразе, пародије и других. Исто тако и нивои појма интертекстуалности су вишеструки: општа инертекстуалност подразумева да је текст интертекстуална конструкција и да је интертекстуалност карактеристика сваког текста, док посебна интертекстуалност представља приметну, намерну, материјално видљиву одлику неког књижевног текста, врсте, жанра или стила (Јуван, 2013: 49-57).

Важно питање за наш рад јесте да ли се и зашто интертекстуалност постмодернизма разликује од интертекстуалности уопште или од интертекстуалности неких других праваца. Марко Јуван (2013: 101) наводи да је „интертекстуалност у постмодернизму „централно конструкцијско начело“, испостављено и метафикционално рефлектовано“. Интертекстуалност је „судбина постмодернизма“ који се окреће књижевности, уметности и историји, а не објективној стварности (Јуван, 2013: 100). Овакво разумевање интертекстуалности у постмодернизму је у складу са Бартовом тезом да текст не може да живи ван бесконачног текста, те је тако и интертекстуалност ,услов саме текстуалности“" (Хачион, 1996: 214). Према Линди Хачион (Linda Hutcheon) (1996: 199-200) постмодерна интертекстуалност је:

„Формални израз жеље да се попуни празнина између прошлости и садашњости читаоца и жеље да се прошлост напише у новом контексту. [...] То није покушај да се поништи или избегне историја. Уместо тога, у питању је директно суочавање прошлости књижевности и прошлости историогра- 
фије, пошто је и она изведена из других текстова (докумената). Она /постмодерна интертекстуалност/ употребљава и злоупотребљава интертекстуалне одјеке, тако што уписује њихове моћне алузије и потом ту моћ руши путем ироније. ${ }^{“ 4}$

Важан термин који Линда Хачион везује за постмодернизам и постмодерну интертекстуалност је пародија. Међутим, ту се крије још једна противречност постмодернизма, јер пародирати „не значи само уништити прошлост; у ствари, значи учинити прошлост светом, али и оспорити је“ (Хачион, 1996: 211). Постмодерни текст уместо комуникације са спољашњим светом, првенствено се повезује са прошлошћу, односно другим текстовима. Он може да се надовезује на други текст, да га пародира, да га преиспитује или наново исписује, али је он пре свега интертекстуална творевина. Будући да се са поновним ишчитавањима и различитим читаоцима смисао текста сваки пут изнова ствара, читалац постаје најважнија карика у поцесу рађања значења. У том смислу, један од задатака читаоца и књижевне анализе дела може да буде препознавање интертекста ${ }^{5}$, увиђање разлике у значењу и коначно, проналажење новог смисла. Уметност постмодернизма је плодно тле за овакву анализу јер интертекстуалност представља њену препознатљиву одлику, а начини на који се дела постмодернизма поигравају са интертексовима пружају широк дијапазон варијација. То је

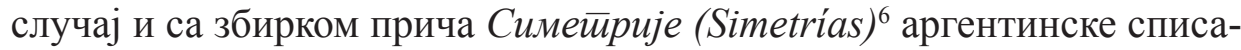
тељице Луисе Валенсуеле (Luisa Valenzuela).

\section{2. Постмодерна бајка}

Збирка Симейрије сачињена је од пет поглавља Резови (Cortes), Oлује (Tormentas), Месијансивва (Mеsianismo), Бајке из йакла (Cиеntos

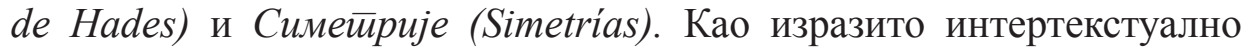
издваја се поглавље Бајке из йакла које има шест прича чији су ин-

4 Hutcheon, L. (1988). A poetics of postmodernism: history, theory, fiction. London: Routledge

5 „Текст (или скуп текстова) који се цитира, наново пише, продужава и, уопште, трансформише неким другим текстом и то овај потоњи чини смисленим.“ (Принс, 2011: 76)

6

Објављена 1993. године 
тертекстови бајке за децу. Прича Ако је ово живой, ја сам Црвенкайa (Si esto es la vida, yo soy Caperucita Roja) трансформише бајку Црвенкайа. Интертекст приче Найреgак се не може заусйавийи (El progreso no se detiene) је бајка Усйавана лейойица. У причи 4 иринца 4 (4 Príncipes 4) појављују се позајмице из неколико бајки: Принщеза и жабаи, Усйавана лейойица и Принщеза на зрну ірашка. Прича Густиина речи (La densidad de palabras) као интертекст користи бајку Виле Шарла Пероа ${ }^{7}$ (Charles Perrault), а у причи Авайари (Avatares) присутни су елементи бајки Снежана и сеgам йайуљака и Пейуљуїа. На крају, прича Kључ (La llave) успоставља однос интертекстуалности са бајком Плавобраяи Шарла Пероа.

Ауторка са разлогом трансформише ову књижевну врсту. Бајке су пре свега намењене деци и омладини, главни јунаци су најчешће женски ликови, а радње бајки говоре о поступцима или особинама који бивају кажњени или награђени. Оно понашање или особину која се кажњава треба потиснути, док оно које бива награђено треба неговати. Дакле, бајке дају модел узорног понашања које треба следити, а из самих радњи се види да се тај модел најчешће односи на девојчице, будући да се радња махом одвија око женских ликова, док су мушки скрајнути и недовољно изграђени. Валенсуела преобличавањем модела који се вековима стављају пред децу, подстиче читаоца на преиспитивање порука које одређене бајке шаљу. Оваква идеја пародирања старе и слања потпуно нове поруке је сама по себи постмодерна, као и начини помоћу којих то подстиче. У свих шест прича могуће је уочити сличне поступке прилагођавања интертекстова као што су трансформација радње, додатно описивање ликова и ситуација, промена приповедача, психологизирање споредних ликова, хумор и иронија.

Иако приче углавном следе радњу познату из бајки, на појединим местима се оригинална радња мења. Бајке препознајемо управо по окосници саме радње која најчешће остаје иста или по поступцима или особинама ликова, јер су сама имена подложна промени. У причи

7 Перо је француски писац модерних бајки из 17. века, он је писац многих бајки које валенсуела наново исписује, али најпознатије бајке попут Црвенкапе, Пепељуге и Успаване лепотице присутне су у различитим обрадама, између осталог и у потоњим обрадама браће Грим (Grimm), тако да се Валенсуела не надовезује искључиво на верзије Шарла Пероа. 
у којој се наново исписује бајка о Црвенкапи, радња је наизглед иста, мајка шаље своју ћерку да однесе баки храну. На путу до бакине куће, девојчица мора да прође кроз шуму, због чега је мајка упозорава да се не задржава успут и да се чува вука. Међутим, пут до бакине куће у Валенсуелиној причи много дуже траје, Црвенкапи се намећу многа метафизичка и филозофска питања, па тај пут највише подсећа на сам живот: „Por un camino tan intenso como éste, tan vital, llegar a destino no parece atractivo". ${ }^{8}$ (Valenzuela, 1999: 67). У причи Найреgак се не може заустиавити и радња је обогаћена бројним детаљима везаним за вилу која је бацила чини на Успавану лепотицу и о њеном животу са принцем након буђења. Тај живот након буђења представљен је потпуно другачије него у бајци. За разлику од бајке које се завршава срећним и дуговечним браком, Валенсуела представља једну несрећну жену, која на крају почне да се бори за своје потребе: „La ama así у no le importa mientras ella no intente abandonar sus aposentos o enterarse de las cosas de corte. [...] La ama mientras de sus gráciles brazos van creciendo poco a poco unos zarcillos viscosos que lo atrapan." (Valenzuela, 1999: $75)^{9}$ У причама Густиина речи и Кључ Валенсуела корсти радњу интертекста као увод за своју причу, те тако радња бајке Виле је заправо повод да се исприча прича о „лошој сестри“, а бајка Плавобраgи је надограђена причом о радозналости у новом контексту и времену. У причи 4 Приниа 4 радња се највише мења, јер принцеза која љуби жабца остане нема, принц који треба да пробуди успавану лепотицу, не жели да је разбуди својим пољупцем, а преосетљивост принцезе на зрну грашка постаје врлина коју тражи трећи принц. Када упоредимо свих шест прича, трансформације оригиналних радњи су свуда приметне, али нису претеране. Оно што се значајно мења су детаљи, описи ликова, описи места и перспектива из које је представљена радња.

У својим причама Валенсуела махом напушта приповедање у трећем лицу и свезнајућег приповедача, а ту улогу препушта неком

8 „Када је пут овако узбудљив, овако животан, онда долазак на циљ и не делује примамљиво.“ (Превод: Ана Марковић) (Валенсуела 2016: 99)

9 „Воли је баш такву и не мари све док она не покушава да напусти своје одаје и обавести се о дворским пословима.[...]Воли је док из њених грациозних руку мало-помало ничу лепљиве рашљике које га заробљавају.“ (Превод: Ана Марковић) (Валенсуела 2016: 108) 
од ликова бајки које наново исписује. У првом лицу су исприповедане приче Ако је ово живой, ја сам Црвенкайа, Гусиинна речи и Кључ док се приповедање у трећем лицу задржало у преосталим причама. Приповедач приче Ако је ово живой, ја сам Црвенкайа је углавном сама Црвенкапа, али се смењују и делови у којима приповедају мајка и вук, који се на крају стапају у једно „La reconozco, lo reconozco, me reconozco.” (Valenzuela, 1999: 70) ${ }^{10}$ Прича Густиина речи исприповедана је у првом лицу, приповедач је „зла“ сестра из бајке Виле која говори о доброј и лошој сестри. Великодушна сестра је награђена тако што из њених уста излазе драгуљи и бисери када говори, док је она лоша кажњена тиме да из њених уста излазе жабе и змије. Приповедање у првом лицу пружа нову перспективу причи тиме што „зла“ сестра проговара о својој судбини:

„Y fue así como ahora estoy sola en el bosque y de mi boca salen sapos y culebras. No me arrepiento del todo: ahora soy escritora. Las palabras son mías, soy la dueña, las digo sin tapujos, emito todas las que me estaban vedadas; las grito, las esparzo por el bosque porque se alejan de mí saltando o reptando como deben, todas con vida propia." (Valenzuela, 1999: 82) ${ }^{11}$

Причу Кључ приповеда жена из бајке Плавобраgи која говори о свом супругу, човеку плаве браде који се много пута женио и убијао своје жене, њихова тела су била у једној забрањеној одаји. Једнога дана одлучио је да стави своју жену на пробу подаривши јој све кључеве и рекавши јој да не сме да иде у забрањену одају. Њена радозналост јој није дала мира, ушла је у забрањену просторију што је муж сазнао на основу кључа умрљаног крвљу. Од смрти су је спасила два брата. У Валенсуелиној причи жена Плавобрадог приповеда о ономе

10 „Препознам је, препознам га, препознам се.“ (Превод: Ана Марковић) (Валенсуела, 2016: 102)

11 „И тако се десило да сам сада сама у шуми а из мојих уста излазе жабе и змије. Ни најмање се не кајем: сада сам књижевница. Речи су моје, ја сам њихова газдарица, казујем их и без устезања, на сав глас говорим све оне речи које су ми некад биле забрањене; узвикујем их, расипам их по шуми, јер оне се сад удаљавају од мене скакућу или гамижу, и свака живи својим животом.“ (Превод: Ана Марковић) (Валенсуела, 2016: 117) 
што се на суров начин кажњава у бајци, о радозналости: „Pero hay que reconocer que empecé con suerte, a pesar de aquello que llegó a ser mi defecto por culpa de un tal Perrault -que en paz descanse-, el primero en narrarme." (Valenzuela, 1999: 94) ${ }^{12}$

Променом приповедача прича постаје личнија, субјективнија, акценат није на приповедању већ добро познатог следа догађаја, већ на осликавању осећања, осветљавању других могућности, постављању нових питања. Читалац се налази пред отвореним питањима, попут следећих: Да ли су поруке које нам бајке шаљу у складу са нашом природом и да ли је оно што се у њима критикује стварно и искључиво лоше?. Као што у причи Кључ приповедач наводи читаоца на преиспитавање радње бајке, указујући на мањкавости интертекста: „YY nadie se pregunta qué habría sido de mí, en un castillo donde había una pieza llena de mujeres degolladas y colgadas de ganchos en las paredes, conviviendo con el hombre que había sido el esposo de dichas mujeres y las había matado seguramente de propia mano?"(Valenzuela, 1999: 95) 13 $^{13}$

У преостале три приче, приповедање је у трећем лицу, али се не приповеда о главним јунацима бајки, већ о споредним или недовољно изграђеним ликовима. Такву врсту трансформације интертекста називамо психологизирањем споредних ликова. У Валенсуелиним причама рефлектор се помера са принцеза на принчеве, са маћеха на очеве, односно на ликове за које знамо да постоје, али не знамо ништа о њима. Ауторка се надовезује на њихово пуко постојање и гради потенцијалну другу страну новчића. Тако изграђује лик виле која баца чини на успавану лепотицу, гради ликове очева Снежане и Пепељуге о којима из дечијих бајки сазнајемо тек неколико података од стране свезнајућег приповедача. Поред тога, описује принчеве из бајки Принщеза и жабаи, Усйавана лейойица и Принцеза на зрну ірашка, који су у бајкама неизграђени и типизирани. Нарочито се

12 „Али ваља признати да сам почела срећна, упркос ономе што је касније названо мојом маном кривицом извесног Пероа - нек му је лака земља - првог који је приповедао о мени.“(Превод: Ана Марковић) (Валенсуела, 2016: 131)

13 „А нико се не пита шта би било са мном у замку у коме је постојала соба пуна прекланих жена обешених о куке на зидовима да сам наставила да живим с човеком који је био супруг поменутих жена и који их је зацело убио сопственом руком?“ (Превод: Ана Марковић) (Валенсуела, 2016: 133) 
издваја прича Аватиари у којој разговарају Господар Југа и Господар Севера, односно очеви Пепељуге и Снежане. Ауторка се бави фигурама очева уместо маћехама које у бајкама традиционално наносе зло својим пасторкама. Пепељугин отац, Господар Југа представљен је као насилан, хладан отац, који је Пепељугу терао на најтеже кућне послове и омаловажавао је: „А estas criaturas debe tratárselas con mano dura, la mía hasta su nombre ha perdido, mis hijastras que son la mar de las graciosas la llaman por un apelativo que habla de su baja condición y de su inmundicia." (Valenzuela, 1999: 90) ${ }^{14}$

Снежанин отац, Господар Севера, представљен је кроз инцестуозне пориве које гаји према ћерки и тиме изазива и храни маћехину мржњу према Снежани:

„Y ella me interroga cuando no puede más: Espejo, Espejo, me llama, porque mi esposa debe mantenerme el respeto y dirigirse a mí por mi nombre de familia, le tengo prohibido pronunciar mi primer nombre, sólo a mi dulce nieves le permito tamaña confianza, Espejo, Espejo, me llama entonces Gumersinda, y después me pregunta. ¿Quién es la más bella entre las bellas? Yo naturalmente contéstale siempre: Mi Nieves, Mi Blanquita. Esta respuesta, legítima por cierto, tiene el añadido valor de enloquecerla de furia, y a mí me divierte, me hace reír a mandíbula batiente como en los viejos tiempos de pillajes y saqueos que ambos tanto añoramos.“ (Valenzuela, 1999: 89) ${ }^{15}$

14 „Према тим створењима треба се односити са чврстом руком, моја је чак изгубила и име, па је моје пасторке,које су невероватно забавне, зову именом које одговара њеном ниском статусу и њеној поганости. (Превод: Ана Марковић) (Валенсуела, 2016: 126)

15 „А она ме пропитује када не може више да издржи: Огледало, Огледало, каже ми - јер моја супруга мора да се односи према мени с поштовањем и да ми се обраћа породичним именом, забранио сам је да ме зове по личном имену, такву блискост допуштам само својој слаткој Снежани - Огледало, Огледало, зове ме тада Гумерсинда, а затим ме пита: Најлепша на свету ко је? Ја јој наравно увек одговарам: Моја Снежана, моја лепа бела Снежана. Овј одговор осим што је тача, има додатну вредност зато што је излуђује од беса, а мене забавља, ја се смејем грохотм као у стара времен лупештва и пустошења за којима обојица толико чезнемо.“ (Превод: Ана Марковић) (Валенсуела, 2016: 125-26) 
Примећујемо да маћеха свог супруга, Снежаниног оца назива Огледало. у Валенсуелиној причи представљају огледало и Снежанин отац су једно, на тај начин мушкарац постаје онај који мери женску лепоту и уноси раздор међу женама, а не видовито огледала и женска завист (Марковић, 2013:147).

Вештила (Brhada) из приче Найреgак се не може заустиавитии је зла вила из бајке Усйавана лейойица. О њој у бајци сазнајемо само да је зла и да баца чини на малу принцезу, док је Валенсуела представља детаљније и другачије, са више података о њеном физичком изгледу и животу. У тим описима не видимо злобу, већ неправедну запостављеност од стране друштва, пре свега због своје разборитости: „el hada más sensata" (Valenzuela, 1999: 71) ${ }^{16}$. Занимљиво је да је Валенсуела представља као тамнопуту, чиме терети краљицу и краља који је нису позвали на прославу за дискриминацију.

Принчеви у причи 4 Принца 4 су заузели место које принцезе заузимају у бајкама где приповедач описује њихов изглед, одећу, понашање или навике. Валенсуела сада говори о принчевима из познатих бајки. Први принц је принц из бајке Принцеза и жабаи и поред тога што се говори о њему, овде се мења и радња јер се принцеза која га је пољубила променила: „La doncella que lo besó ya no es de este mundo. En su momento el príncipe no quiso dejar una testigo de la mutación por él sufrida, y ahora se arrepiente." (Valenzuela, 1999: 76) ${ }^{17}$ Сада принц тугује јер принцеза више не може да исприча шта се догодило. Други принц је принц из Усйаване лейойще који је пронашао праву принцезу, али не жели да је пробуди, јер оне које је до тада љубио постану превише захтевне, боре се за своје жеље и потребе, он заправо жели уснулу девојку, јер како приповедач каже: „Nunca ha logrado aprender cómo despertar lo suficiente sin despertar del todo" (Valenzuela, 1999: 77) ${ }^{18}$ Трећи принц је принц из бајке Принцеза на зрну ірашка, који не жели да се ожени, али породица то од њега захтева. На крају му

16 „Најразборитија вила” (Превод: Ана Марковић) (Валенсуела, 2016: 103)

17 „Девојка која га је пољубила није више од овог света. У то време принц није желео да остави сведокињу промене коју је претрпео, а сада се каје.“ (Превод: Ана Марковић) (Валенсуела, 2016: 109)

18 „Никада није успео да научи како да пробуди довољно али да не пробуди сасвим.“ (Превод: Ана Марковић) (Валенсуела, 2016: 111) 
се толико осетљива принцеза која испод силних душека осећа и зрно грашка учинила савршеном, јер све што је требало да обуче за свадбу њој смета, што њему омогућује да остане нежења: „... sin jamás de los jamases convocar a hada alguna por miedo que le arruinara el pastel. no precisamente el de bodas." (Valenzuela, 1999:78) ${ }^{19}$

Грађење споредних ликова праћено је хумором. Ауторка спретно уноси комична размишљања ликова или опаске приповедача помоћу којих држи читаочеву пажњу и пародира поруке интертекста. Овакви примери су бројни у причама Луисе Валенсуеле. Један се налази у комичном представљању принца из Усйаване лейойице: „Entregado a la búsqueda, el príncipe de nuestra historia besa por acá y po allá sin prestar demasiada atención a los resultados." (Valenzuela, 1999: 77) ${ }^{20}$ или када од „зле“ сестре из приче Густиина речи траже да заћути: „Еl mejor adorno de la mujer es el silencio, me decían. En boca cerrada no entran moscas. ¿No entran? ¿Entonces con qué alimento a mis sapos?, pregunte alarmada[...]” (Valenzuela, 1999: 84) ${ }^{21}$ Валенсуела вешто користи иронију да исмеје потребу да се вечно остане млад и леп коју друштво намеће: „Era desdentada, desgreñada, desfachatada y, pero aún, vieja, cualidad esta última también poco apreciada en tiempos cuando casi todos tenían la suprema cortesía de morir en la flor de la edad." (Valenzuela, 1999: 71) 22

Помоћу свих наведених промена, Валенсуела пародира бајке које користи као интертекстове са циљем да укаже на идеолошке мањкавости порука које оне пружају. А пародија је, према речима Зденка Лешића (2008: 278): „најконзистентнији примјер иниеериеекс$\bar{u} у а л н о с \bar{u} u$ : она је по интенцији „метатекст“, тј. текст који се равна према неком другом, али као његово критичко разоткривање.“

19 „...никад ама баш никад није позвао у помоћ ниједну вилу у страху да му не помрси рачуне.“ (Превод: Ана Марковић) (Валенсуела, 2016: 113)

20 „Посвећен потрази, принц из наше прича љубака овде и онде, не обраћајући нарочиту пажњу на резултате.“ (Превод: Ана Марковић) (Валенсуела, 2016: 110)

21 „Најбољи украс жене је ћутање, говорили су ми, у затворена уста не улећу мушице. Не улећу? Чиме онда да нахраним жабе?, питала сам узнемирена[...]“ (Превод: Ана Марковић) (Валенсуела, 2016: 120).

22 „Била је безуба, рашчупана, бестидна, и још горе, стара, а то њено последње својство такође су мало поштовали у временима када су сви тако врхунски увиђавно умирали у цвету живота.“ (Превод: Ана Марковић) (Валенсуела, 2016: 103). 


\section{1. Нови смисао}

Кристофер Батлер (Christopher Butler) (2012: 132) тврди да су постмодернисти углавном песимисти, што можемо приметити и у Валенсуелиним причама, „живот је разочарање“ ${ }^{\text {“23 каже у причи } A \kappa o ~ j e ~}$ ово живой, ја сам Црвенкайа. Међутим, Валенсуелин песимизам се највише односи на положај жена у друштву и због тога она у својим делима првенствено „указује на неравноправан положај жена и неопходност њихове еманципације у ауторитарном и патријархалном друштву“ (Дицков, 2016: 278). У том кључу се могу и тумачити њене приче. Заједнички циљ Бајки из йакла је да критикују и пародирају идеолошке обрасце представљене у бајкама, нарочито онај део који се односи на особине и улоге жена које им друштво намеће. Нападом на ауторитет, што је поново постмодернистиички акт (Батлер, 2012: 127), Валенсуела преиспитује моделе које патријархално друштво ставља пред жене, у овом случају пре свега пред девојчице. То чини, између осталог, избацивањем свезнајућег приповедача коме не може да се верује и препушта женама да створе свој језик, макар он био од жаба и змија као у причи Густиина речи (Марковић, 2013: 168). Критикује друштво које женама намеће лепоту, ћутљивост, незаинтересованост за дешавања око њих, понизност као примарне женске особине. Од мушкараца са друге стране, не знамо шта се очекује, јер се они обично појављују као спас, што опет наводи на закључак да је жена без мушкарца (принца, оца, брата) угрожена и непотпуна. Оне особине које треба укротити, које се у бајкама кажњавају, постају пожељне у Валенсуелиним причама:

„Непослушне јунакиње попут Црвенкапе, жене Плавобрадог и охоле сестре из „Вила“ постају позитивни модели у овим феминистичким реимагинацијама и представљају симболе виталног трагања за смислом и еротског искуства („Ако је ово живот, ја сам Црвенкапа“), женског књижевног стваралаштва („Густина речи“) или пак политичке побуне („Кључ“).“ (Марковић, 2016: 153)

23 Batler, C. (2002). Postmodernism, A Very Short Introduction. Oxford University Press 
Валенсуелине јунакиње су храбре, самосвесне, разборите, радознале, жељне слободе, помало дивље, младе, али и старе. Брак није представљен идилично, и не представља крај живота сваке жене (као што је случај у бајкама), већ заједица у којој жена има слободу, односно право да се избори за себе, као у причи Найреgак се не може заустиавити . Поред тога што деконструише „узорне“ женске особине и брак, Валенсуела уништава и идиличну слику принца ослободиоца (Марковић, 2013: 155). Очеви и принчеви нису савршене фигуре, већ су такође подложни критици, а у Валенсуелиној критици су насилни, перверзни, себични, саможиви, сујетни, егоистични: „A lo largo de siglos me huyen los hombres porque he hecho de pecado la virtud y eso no lo perdonan."(Valenzuela, 1999: 94) ${ }^{24}$

\section{3. Закључак}

Могућа су различита тумачења Валенсуелиних прича, али извесно је да оне успевају да наметну потребу за преиспитивањем канона, ауторитета, традиције, као и идеолошких, културолошких и друштвених норми и очекивања. Ауторка пародијом вешто постиже свој циљ: „Se juegan a otros juegos más sutiles y recientes. Se juega al Final de la historia, o al Posmodernismo, juego este que es pura parodia, que nunca es tomado en serio, gracias a lo cual cumple con precisión su cometido." (Valenzuela, 1999: 79) ${ }^{25}$

Ове приче су прави представник постмодернизма, јер у деконструкцији модела које друштво намеће женама, не осврћу се на објективну стварност, већ на саму традицију, односно на сам текст. Та текстовна комуникација је у складу са Бартовом тезом о бесконачном тексту коју смо поменули у уводу рада. Поред тога што је циљ постмодернистички, а то је урушавање ауторитативних друштвених образаца, и само средство којим се овај циљ постиже је препознатљива одлика овог правца, а то је интертекстуалност и то пре свега,

24 „Већ вековима мушкарци беже од мене пошто сам од греха направила врлину а они то не опраштају.“ (Превод: Ана Марковић) (Валенсуела, 2016: 131)

25 „Сада се играју друге, новије и префињеније игре. Игра се Крај Историје или Постмодернизам, а ова последња игра је чиста пародија, која се никада не схвата озбиљно, захваљујући чему испуњава без грешке свој задатак.“ (Превод: Ана Марковић) (Валенсуела, 2016: 114) 
пародија. Трансформисањем оригиналне радње, допуњавањем описа ситуација, дописивањем мотивације која покреће на радњу, психологизирањем споредних или неизграђених ликова, хумором и иронијом ауторка указује на недоследности, неприродности, неправедности и суровости представљене у интертекстовима које наново исписује.

\section{Литература}

Batler, K. (2012). Postmodernizam: sasvim kratak uvod. Beograd: Službeni glasnik.

Bužinjska, A. (2009). Poststrukturalizam. In A. Bužinjska, M .P. Markovski, Književne teorije XX veka, (pp. 331-391). Beograd: Službeni glasnik.

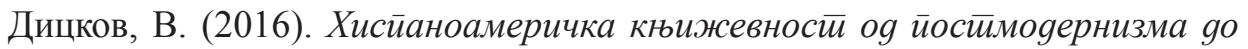
Посишбума.Београд: Филолошки факултет.

Juvan, M. (2013). Intertekstualnost. Novi sad: Akademska knjiga.

Lešić, Z. (2008). Teorija književnosti, Beograd: Službeni glasnik.

Marković, A. (2013). La identidad femenina y las relaciones de poder en los relatos de Luisa Valenzuela. Barcelona: Universitat de Barcelona. Доступно преко: http://diposit.ub.edu/dspace/handle/2445/44343 (10.02.2019)

Marković, A. (2016). „Simetrije“ i potraga za ženskim glasom: pripovedanje i istina, In L. Valensuela, Simetrije. (pp.151-155). Novi Sad: Agora.

Prins, Dž. (2011). Naratološki rečnik. Beograd: Službeni glasnik.

Hačion, L. (1996). Poetika postmodernizma: istorija, teorija, fikcija, Novi Sad: Svetovi.

\section{Извори}

Valenzuela, L. (1999). Cuentos completos y uno más. Ciudad de México: Alfaguara

Valensuela, L. (2016). Simetrije. Novi Sad: Agora (prevela Ana Marković). 
Isidora M. Kalović

\title{
INTERTEXTUALIDAD POSMODERNA EN LOS CUENTOS DE LUISA VALENZUELA
}

\begin{abstract}
Resumen
En este trabajo investigamos y analizamos la presencia de la intertextualidad posmoderna en los cuentos del libro Simetrías de la escritora de Argentina, Luisa Valenzuela. En el capítulo Cuentos de Hades Valenzuela reescribe los cuentos de hadas y en todos los seis cuentos del capítulo encontramos procesos de transformación de intertextos mutuales. Llegamos al nuevo sentido del texto gracias a la parodia de cuentos de hadas cuya interpretación tradicional y mensajes que mandan la autora critica. Valenzuela hace que los lectores interroguen y piensen sobre los valores que la sociedad y tradición imponen, especialmente sobre los valores que afectan a la figura de mujer en una sociedad. Debido a la gran presencia de la intertextualidad, parodia, crítica, compromiso literario, interrogación de autoridad y tradición, tanto estos cuentos, como la intertextualidad que se establece en sus páginas, son posmodernos.
\end{abstract}

Palabras clave: Luisa Valenzuela, postmodernismo, intertextualidad, intertextualidad posmoderna, intertexto, cuento de hada, cuento 